\title{
Royal Society urges rethink on degrees
}

London. British universities should abandon the traditional 'honours' system for classifying undergraduate degrees on a single scale of 'firsts' to 'thirds', and adopt the practice followed by the United States and many European countries, where a more comprehensive record of achievement is provided, according to a report published this week by the Royal Society.

The report also endorses an initiative being backed by the Institute of Physics through which some universities have introduced simplified undergraduate courses in science subjects, complemented by additional studies, leading to a four-year degree course, for those intending to become professional physicists.

The widespread adoption of four-year courses for science degrees has been opposed by the government on the grounds of cost. But the Royal Society suggests that the physicists' approach, which includes the possibility of "less able" students finishing their higher education after only two years, should be extended to other areas of science and mathematics.

"We have no doubt that an extended and enhanced degree is the minimum required to educate scientists and engineers to full professional levels comparable with those reached by their peers in other EC countries", says the report, which was prepared by a study group chaired by Sir Eric Ash, the former rector of Imperial College, London.

Its main recommendation is that higher education institutions need to be able to offer a range of qualifications, and must allow students to select those most appropri-

\section{Future of Rutherford under debate}

London. Britain's largest surviving public research laboratory, the RutherfordAppleton Laboratory (RAL), will begin life under the new arrangements for supporting research as a dependant of the Engineering and Physical Sciences Research Council (EPSRC). But proposals for more radical reorganization are being drawn up and are due to be completed by the middle of this month, in time for a decision by next April, when the new system will come into effect.

RAL, now financed directly by the Science and Engineering Research Council (SERC), is due to be amalgamated with the Daresbury Laboratory. The government's white paper on research decreed that the two laboratories would be run directly by the Office of Science and Technology by its director-general of research councils, whose appointment is imminent.

The rationale of the combined laboratory is that of providing a service for academic research groups. Since the disbandment of its nuclear structure research group last year, ate to their educational and employment needs. And it adds: "We believe that the time to bury the 'honours classification' has arrived."

Meanwhile, the Royal Society is one of a number of scientific organizations that have supported a proposal to establish a new body to oversee the development of vocational qualifications for British scientists, technologists and mathematicians.

The proposal has been made by a working group set up by the Council of Science and Technology Institutes (CSTI). Backed by the Department of Employment, its main goal would be to encourage courses to improve the professional skills of scientists and technologists.

The aim is to achieve this within the framework of the government's broader initiative of introducing National Vocational Qualifications (NVQs) across all sectors of British industry.
A survey conducted by the CSTI on behalf of the department and published earlier this year found that about 600,000 people are currently employed in Britain in jobs where science, technology and mathematics are considered to be the main function.

In addition, 1.7 million have jobs where knowledge of one of these fields is essential to their professional competence. And a further million are in positions where some such knowledge is felt to enhance their effectiveness.

Future employers of scientists are not the only supporters of the initiative. The Institute of Professionals, Managers and Specialists, the trade union representing many government scientists, says that it is keen to be represented on any new overseeing body to ensure that the needs of its members - as well as those of their employing organizations - are fully met by the new qualifications.

David Dickson

\section{Darwin funds to back biodiversity}

London. Twenty-six British and international projects aimed at conserving biodiversity are to be funded under the United Kingdom's Darwin Initiative. Initial grants totalling $£ 3.28$ million over three years, announced on 3 November by John Gummer, the environment secretary, are just over half the $£ 6$ million that the government has promised to spend on the scheme - announced by John Major, the Prime Minister, at last summer's UN Conference on Environment

the Daresbury Laboratory's chief role is as Britain's synchrotron radiation laboratory, widely used by non-British research groups.

The Rutherford-Appleton Laboratory proper, 80 miles south of Daresbury, owes its existence to the merger in the $1970 \mathrm{~s}$ of radio research and high-energy physics laboratories on a site adjoining the Harwell laboratory of the UK Atomic Energy Authority

The amalgamated RAL will employ well over 1,500 qualified scientists. Its present anxiety is that there is no obvious place in what is intended to be a market-led research enterprise for a general service laboratory with its particular mixture of skills.

The laboratory's preferred option appears to be an arrangement under which the research councils would purchase a range of research services much like that now on offer. Other options, especially that in which research services would be purchased directly by those holding research grants, are less likely to be welcome. John Maddox and Development in Rio de Janeiro.

High priority was placed by the committee which advised the Department of Environment on the value of training conservation biologists in developing countries: training makes a little money go a long way. As a result, $£ 1.53$ million has been allocated to nine projects explicitly concerned with training.

The biggest beneficiaries are the World Wide Fund for Nature (two projects worth a total of $£ 522,100$ ), a project sponsored by the British Ecological Society $(£ 356,000)$ and the International Mycological Institute (IMI, £305,300). "Training and education is one of the most effective ways of using a resource of this kind", says David Ingram of the Royal Botanic Gardens, Edinburgh, a sponsor of several bids to the advisory committee.

But the boundary between support for training and research is not rigid. David Hawksworth of the IMI says that its award will fund 22 'Darwin fellows' in several developing countries, concerned with research problems in parasitology, bacteriology and entomology, as well as mycology.

Of the $£ 6$ million, the advisory committee spends $£ 1$ million in the first year, with $£ 2$ million and $£ 3$ million in subsequent years, allowing for continuing commitments made in earlier years. This gives the advisory committee plenty of room to play with, says Sir Crispin Tickell, warden of Green College, Oxford, and chairman of the committee, who urges institutions with good ideas to send in applications. Further announcements are expected early next year, as applications are processed. Henry Gee 